\title{
НАРОДНІ ВІРУВАННЯ ПРО ЕПІЛЕПСІЮ: СИМВОЛІЧНИЙ І СЕМІОТИЧНИЙ АСПЕКТИ (ЗА МАТЕРІАЛАМИ ЕКСПЕДИЦІЇ ЧЕРНІГІВСЬКИМ ПОЛІССЯМ)
}

\author{
Дар'я АНЦИБОР
}

Кандидатка філологічних наук, наукова співробітниця відділу Державного наукового центру захисту культурної спадщини від техногенних катастроф, УКРАЇНА

DOI $10.25128 / 2304-1222.19 .49 .08$

The article examines the complex of traditional folk beliefs about epilepsy, which covers the concept of the etiology of the disease, preventive measures, diagnosis and ways to overcome the illness. The article gives a detailed anal ysis of the modern irrational methods of fighting against epilepsy and the symbolic component of traditional heal ing and magic rituals in Se meni vsky and Novgorod-Siversky districts of Chemihiv region. Old fears, al cohol addiction, and congenital diseaseareamong thecauses of epilepsy which werecollected during the fieldwork. The article provides a detail ed overview of the main irrational treatment methods in the study areas. It is proved that their main purpose is to deceive the disease, which is real ized through symbolic burial and rebirth, as well as approaching the non-human condition. Such methods include covering with a black headscarf, stepping over a patient at the doorstep of a church, and sitting with a naked buttock on a patient.

K eywords: epilepsy, healing practices, folk prayers, charms.

У статті здійснюється аналіз комплексу народних вірувань про епілепсію, який охоплює уявлення про етіологію цієї хвороби, превентивні засоби, діагностування та способи подолання недуги. Робота має на меті проаналізувати сучасні ірраціональні методи боротьби з епілепсією в локальному побутуванні та детально розглянути символічну складову традиційних лікувально-магічних обрядодій. Для дослідження було обрано Семенівський та Новгород-Сіверський райони Чернігівської області. Зафіксовано такі уявлення про причини появи епілепсії, як задавнений ляк або вроки, алкогольна залежність та вродженість. У статті здійснено детальний огляд основних методів ірраціонального лікування, які побутують у досліджуваних районах. Доведено, що основною їх метою $є$ обман хвороби, що реалізується через символічне поховання й переродження, а також наближення до стану не-людини. До таких методів належать накривання чорною хусткою, переступання через хворого на порозі церкви та сідання оголеним задом на хворого.

Ключові слова: народна медищина, епілепсія, лікувально-магічні практики, замовляння, народні молитви.

Artykuł ten stanowi próbę analizy spektrum wierzeń ludowych o epilepsji zawierający domniemania o etiologii tẹ choroby, zabiegi zapobiegawcze, diagnozę i sposoby kuracji. Praca 
ma na celu zbadanie współczesnych irracjonalnych metód walki z padaczką w zakresie lokalnym i szczególny przegląd symboliki tradycyjnych rytuałów leczniczo-magicznych. Do ba dania wybrano rejon Semeniwski i Nowhorod-Siwerski obwodu Czernihowskiego. Zarejestrowano następujące domniemania o przyczynach padaczki: stłumione lęki, klątwy, uzależnienie od alkoholu czy cecha wrodzona. Artykuł stanowi też szczegółowy przegląd najważniejszych metód irracjonalnej kuracji, które są rozpowszechnione na tym terenie. Udowodniono, że podstawowym ich celem jest okłamywanie choroby poprzez symboliczny pochówek i przerodzenie się osoby oraz udawanie nieludzkiego bytu. Wśród tych metód jest pokrycie człowieka czarną chustą, przejście przez chorego leżącego na progu cerkwi i siedzenie na chorym nagim tyłkiem.

Słowa kluczowe: medycyna ludowa, epilepsja, praktyki lecznicze i magiczne, modlitwyludoweб zamawianie choroby.

Епілепсія, що передбачає розлад мозкової діяльності й супроводжується повторюваними нападами, є одним із найпоширеніших хронічних неврологічних захворювань серед людей. Через комплексність факторів, які викликають цю хворобу, недостатній рівень обізнаності про неї та наявну стигматизацію хворих, в українському суспільстві зберігається та застосовується чимало ірраціональних практик ії лікування засобами народної медицини. Традиційно епілепсію ставили в один ряд із найстрашнішими захворюваннями, що зумовило появу цілого комплексу народних уявлень про етіологію та способи подолання цієї недуги, які мають свої особливості в різних регіонах України.

Робота має на меті проаналізувати сучасні ірраціональні методи боротьби 3 епілепсією в локальному побутуванні. Для дослідження було обрано культурний ареал Чернігівського Полісся. Під час написання статті застосовувалися структурносемантичний метод, а також метод порівняльного та семіотичного фольклорного аналізу.

Джерельною базою стали записи, здійснені під час експедиції Державного наукового центру захисту культурної спадщини від техногенних катастроф й зібрані влітку 2019 року в Семенівському та Новгород-Сіверському районах Чернігівської області. 
Комплекс народних вірувань про епілепсію охоплює уявлення про етіологію цієї хвороби, превентивні засоби, діагностування та способи подолання недуги. На підтвердження дієвості останніх нерідко відтворюються наративи про одужання.

Народні уявлення про етіологію. У народних уявленнях про епілепсію, які нам вдалося зафіксувати на північній Чернігівщині, можна виокремити такі фактори пояснення етіології, як вродженість та зовнішній вплив, що може бути ірраціональним та раціональним. Часто респонденти перераховують їх всі одночасно, не виокремлюючи якийсь головний: «Хто каже, шо am icnуга, хто каже, mina am алкаголя там, ну як? Думаю, ну як? Єслі є таке, шо із раждєнія. Бо є, шо із рождєнія дитя вродилось. І вано ат іспуга чи хто його зна, шо вано» [5, с. 15].

До проявів ірраціонального зовнішнього впливу належить поширене уявлення про ляк як причину епілепсії: «Йо природная, а йо такая што магєй спужаџа, дак будє» [2, с. 82]. Часто пояснюється, що це - задавнений ляк, який вчасно «не відробили». Так, одна 3 шептух, до якої постійно звертаються з проханням зняти ляк, пояснювала: «Ну ана пріходіла, я єй нє магла памогть. Удавнілась. Це ж нада як толька сразу, як замєтів... Зразу, дак яно скарєй памагае. А як ано уже удавнілась, як нєвєста уже стала, дак шо ж я памагу уже?» [2, с. 83]. Тож серед шептух побутує уявлення про можливість вилікувати дитячу епілепсію, якщо вчасно звернутися до них, інакше «задавниться».

Однією з причин появи епілепсії називають ії вроджену природу. Тут варто відзначити, що з одного боку, сьогодні серед респондентів фіксується чимало вірувань, що людина може просто народитися з такою хворобою: «Були і такіє, шо па срадству передавалося. Каже, шо там і дід балів сьою балєзю, чи матка, чи хто. А так Бог його знає, чаго вано було» [3, с. 33]. 3 іншого боку, ще прослідковуються, хоча й фрагментарно, поширене колись уявлення про лихого духа, який вселяється в незахищену дитину й трусить ii [Петров 1926; Ганус 2016: 82]. Цей чинник тісно пов'язаний із мотивом зурочення: «Ну, уровське казалі, ета я чула ат людєй, бряхать ня буду» [2, с. 82]. 
Ще одним фактором, що, безперечно, має сучаснішу природу, респонденти називають надмірне вживання алкоголю: «Дак цее ж ад гарєлки!» [6, с. 22]. Дехто вбачає в цьому головну причину появи епілепсії у старшому віці.

Локальні назви хвороби. Дослідниками на території Полісся зафіксовані такі локальні назви епілепсії, як «чорна болєзнь», «чорна слабость», «падуча», «нечіста слабость», «иріпадок», «дитинещь», «родіма», «божа болєзнь» тощо [Никончук, Никончук, Мойсієнко, 2001: 79-80]. Серед назв, які сьогодні побутують у Семенівському та Новгород-Сіверському районах Чернігівської області, переважають «чорна болєзнь», або «чорна», «пріпадок», «уровське», «радімоє». Перша назва пов'язана з чорним кольором, який у традиційній культурі виступає як однозначний символ потойбіччя. Друга синонімічно пояснює стан хворого під час нападу, а останні пояснюють народне уявлення про етіологію - урок або ж вроджену природу захворювання.

Народні способи лікування хвороби. Як уже зазначалося, народні уявлення про епілепсію як хворобу демонічного походження вплинули й на характер лікування, який у традиційній культурі окреслюється ірраціональними методами. Розгляньмо їх детальніше.

Накривання. Одним із способів, поширених серед усіх слов'ян, є накривання хворого чорною хустиною під час нападу. Чорний у традиційній культурі асоціюється 3 кольором смерті, трауру, землі, чужого, демонічного. Вибір хустини такого кольору 3 лікувальною метою може пояснюватися своєрідним інсценуванням смерті хворого, адже накривання обличчя в поховальній обрядовості $є$ архаїчною світовою практикою. Так, Василь Кравченко описував такий метод лікування епілепсії: «»Як тілько перший раз зубачить цю болезнь; як дівчина, то треба чорну курку разорвать надвоє, а як хлопчик, то - чорного півня, і покласти з кроввю гарячого на грудях і накрити чорним чим нибудь. Воно собі успокоїтьця і не будить» [Кравченко 1920: 147]. Тут застосовується на практиці магічний принцип субституції, коли птах має перебрати на себе хворобу. Окремо варто звернути увагу на орнітоморфність цього обряду, адже птахи в традиційній культурі тісно пов'язані із тим світом і символізують душі померлих [дет.: Маєрчик 2011: 235-236], та й символіка чорного кольору знову не випадкова. 
Водночас на користь цього твердження можуть свідчити дані з інших регіонів про субституцію чорної хустини на предмети, які за формою нагадують труну. Наприклад, у західній Малопольщі хвору дитину під час нападу епілепсії клали на поріг або під сволок і накривали діжею. Тоді брали глиняний глек і розбивали його об неї, що мало на меті злякати злого духа, який викликав напади [Усачева 2004: 614]. В Угорській Русі хвору дитину клали на землю та накривали коритом, після чого «батько стане на однім боці на колінки, а мати на другіс і побожать ся, що дітина їх є» [Жаткович 1896: 22].

Дзвенислава Ганус зазначає, що на західноукраїнському пограниччі метод накривання чорною хусткою дитини, хворої на епілепсію, ймовірно прийшов на зміну накриванню нецками (ночвами). Дослідниця справедливо зауважує: «...хвору дитину могли класти в нецки та, поставивши їх біля порога, накривати зверху хустиною, тобто здійснювалася імітація труни» [Ганус 2015: 201]. Варто також зазначити, що саме накривання чорною хустиною семантично наближене до кидання землі на труну померлого.

Ще одним субститутом хустини на Київському Поліссі виступав «талес»єврейський ритуальний одяг, яким накривали хворого на епілепсію [Усачева 2004: 615]. Ймовірно, це мало забезпечити символічний перехід у категорію чужих, у ритуальне не-існування в цьому світі.

Чимало дослідників, описуючи накриття хворого певними предметами, також згадують про ритуальне биття горщика об них або забивання цвяха поруч [Усачева 2004: 614; Кравченко 1920: 45]. Важко не погодитися з припущенням Дз. Ганус, що це робилося з метою символічного пробудження хворого [Ганус 2015: 201]. 3 іншого боку, враховуючи поширеність загальнослов'янського вірування в духа, який буцімто вселяється в тіло хворого (а часто одразу з народження там перебуває та проявляє себе у вигляді епілептичних нападів) [дет.: Петров 1926], таке ритуальне биття могло сприяти швидшому вигнанню його з тіла. Зафіксовані також уявлення про необхідність бити хворого до крові зі схожим поясненням: «щоб злий дух відчув» [Усачева 2004: 614].

Експедиційні записи 3 Семенівського та Новгород-Сіверського районів Чернігівської області підтверджують поширення практики накривання хворого чорною хустиною, але додаткових деталей, як-от биття горщиків чи використання інших супутніх предметів, уже не зафіксовано. 
Переступання. У селі Блистова Новгород-Сіверського району було записано таку лікувальну дію. Хворий на епілепсію лягав на порозі церкви після Великодньої служби, і всі присутні, виходячи з храму, мали переступати через нього [7]. Вважалося, що такий спосіб допоможе подолати хворобу.

У традиційній культурі поріг слугував символічною межею між цим і тим світами, місцем «перебування предків, домашніх духів, яким приносять жертву, тут здійснюється зв'язок із потойбічними силами» [Плотникова 2009: 173].

Як ми вже бачили на попередніх прикладах, лікування епілепсії могло здійснюватися шляхом імітації окремих елементів поховальної обрядовості. Як і накривання, переступання та покладання на поріг чи біля нього символізують тимчасову смерть людини та ії повернення в цей світ оновленою, тобто здоровою. Згадаємо також, що переступання є поширеним способом ірраціонального лікування дітей від різних хвороб, до якого повсякчас прибігали матері [Ігнатенко, Забловський 2008: 45].

Церква постає як особливий локус, де можна заручитися підтримкою божественних сил, а Великодня служба - як особливий час, пов'язаний із вознесінням Христа, його другим народженням. I якщо переступання на порозі храму має символізувати ритуальне вмирання хворого та його переродження, то проведення такої обрядодії має підсилюватися завдяки специфічному хронотопу.

Вичитування молитов. Аналізуючи ритуали та вербальні тексти лікувальномагічного характеру, дослідники неодноразово звертали увагу на персоніфікацію хвороб та їхню міфологічну природу. 3 ними спілкуються, пробують домовитися через посередництво шептух/знахарів, братаються та сватаються, їм погрожують, їх обманюють, залякують тощо. Така стратегія першочергово пояснюється протистоянням людини та не-людини [Усачева 2000: 65]. Тож символічне олюднення хвороби переміщує її з міфологічного простору в людський, що можна інтерпретувати як шанс для хворого на протистояння на «своїй» території.

У с. Костобобрів Семенівського району було записано один текст, який інформантка використовує як сильну молитву від ляку, уроків та епілептичних нападів. 3 їі слів, вона вилікувала нею сусідську дитину від «чорної болєзні»: 
Госпаді, Гасподь, пріступіся, всє балєзні тушися.

Утрєшняя заря, палудєнная, вечєрняя, скула-скуліца, красная дєвіца, я ж тібє вишептую, я ж тібє вигаварюю: падсипную, падлівную, прігаворную, наносную, паддувную, вєтряную, вадяную, даждлявую, грамавую, агнєнную, калючую, свєрблюючую, стрєчную, папєрєчную, ляк, пєрєпалох.

Із рук, із ног, із сєрєдіни живата, русага валаса, румянага ліца, щирага серца, салодкіх пячонок, із буйних плячей, із бєлай касті, iз краснай краві. Тут табі нє хадіть, касті нє ламіть, серца нє сушить
На гарє Сіамскай

стаяв Іван-воін с жєлєзнай палкай, шлі змейниє дочкі.

Куда ідьотє, змейниє дочкі?

Да [ім'ярек] след забірать,

серце осушить

і кров пролівать.

Не йдіте, змейниє дочкі, я вас не пущу, я вас патру, паламаю, за вєтром пущу.

Ідіте на чистиє бари, дє пєвні нє пєють, сабакі нє брєшуть. Там стали пазастілати, кубки паналівати, там тибе напіцца, нагуляцца, накрасавацца, начащацца, ат [ім'я клієнта] всю балєзнь забрать. Мишіний, крисіний, куріний, конский, каровскій, сабачий, кашачий, авєчий, дявочий, парубочий, женскій, мужскій, сіратіни даві. Тут табі ня буть, у галовачкі вєнка нє віть, 
і кров нє пралівать...

Нє я тєбя раділа, тєбя матка [ім'я матері ім'ярек] раділа, нє я атхаділа, атхаділ Гасподь.

Гасподь із помащу,

а я славамі.

Всіх угоднічков прізиваю.

Прідіте, памагітє

рабє Божий [ім'ярек],

крєщьонай, прічащонай.

Варвара-мученіца

памагала тим людям,

памагі [ім'ярек]. серца нє сушит,

касті ні ламіть,

па касті ні хадіть

і кров нє пралівать.

Лєтіть на чистиє бари,

дє півні нє пєят,

сабакі нє брєшут,

там стали пазастілати,

кубки паналівати,

там тибе напіцца,

нагуляцца, накрасавацца,

ат [ім'ярек] всю балєзнь забрать»

[1, c. 6-8].

Після прочитання цього тексту знахарка тричі промовляє: «Залатий вєнєџ адєваєш, сваі різа пакриваєш, всю балєзнь атушаєш». 3 кожною фразою вона проводить своїми руками від голови клієнта до кінцівок його рук, в кінці роблячи жест струшування. Тоді промовляє тричі, спльовуючи на різні сторони: «Тьху ияяму ліху, амін».

Як бачимо, у тексті немає специфічних звертань до епілепсії, але є до ляку та до хвороб загалом. Дослідники лікувально-магічних практик Полісся відзначають особливу побудову замовлянь від ляку та зурочення. Замість одного-двох ключових мотивів (як-от у замовляннях від лихоманки, кровотечі, вивиху тощо), ці тексти є багатокомпонентними, з великою кількістю мотивів і формул, та поліфункціональними [Полесские заговоры 2003: 94-95]. Деякі респондентки, які займаються ірраціональними практиками лікування, говорили про існування окремих молитов від епілепсії, але зараз зафіксувати їх уже не вдалося. Варіанти, які побутували в кінці 1980-х років, вказують на стійке використання чорної 
символіки [Полесские заговоры 2003: 250-267]. Натомість лікувально-магічні формули від ляку й зурочення залишаються серед основних проблем, з якими звертаються до шептух на Поліссі, тому їхнє побутування є дуже широким [Колодюк 2006: 66-69].

Таким чином, деякі шептухи відмовляються лікувати епідепсію, якщо не знають або вже не можуть пригадати вузькопрофільного замовляння, в той час як деякі ситуативно адаптують та використовують інші молитовні тексти від більш розповсюджених проблем.

Наративи про хворих родичів або сусідів, які вилікували епілепсію за допомогою знахарів, достатньо активно побутують серед опитаних респондентів. Подекуди знахарі використовували не лише вербальні формули, але й фітолікування. Так, вважалися помічними відвари з білої водяної лілії, з коріння чорнобилю та з листя черемхи та навіть грибами губ'яками [Ігнатенко, Забловський 2008: 46].

Загалом варто відзначити, що лікування епілепсії ірраціональними методами невпинно поступається місцем доказовій медицині, що помітно зі слів респондентів: «У яйо такіє приступи булі, о, так ета, накрилі [чорною хусткою. Д. А.], і всьо равно нічога ня палучілась, пакуль в Чарнігав ня атвєзлі, да таблєткі, таблєткі, ну і... перерасла» [4, с. 55], «У Вєри дачка он оцей, дак ну, у бальніиу єздять, якісь таблєтки ж праписують, там, псіхіатра» [5, с. 14], «Шо рабить? Фельдмер приїхав, да вколи дав, да й всьо. Шо ти будеш більи рабить? Не жери [горілки. - Д. А.]. Хай тебе вдаве, нехай!» [6, с. 23].

Сідання оголеним на хворого. Як зазначає Валерія Усачова, магічна сила зцілення приписувалася тому, хто вперше побачить напад епілепсії. У словацькому Замагур'ї вірили, що така людина мала сісти голою частиною тіла на обличчя хворого, промовляючи «Чим тебе породила, тим і буду лікувати» або тричі сісти голим задом на корито, під якого поклали хворого [Усачева 2004: 613].

Під час експедиції Чернігівщиною було неодноразово записано практику сідання під час нападу голим задом хворому на голову: «Отак naєхалі на базар $i$ аднага чєлавєка епілєпсія узяла. Дак салдат адін, каже, у шинелі: «Атайдітє всє!». 
Талкушка людєй, упал, сляну пустів і ляжить. I яго б'є, трусє. «Атайдітє всє!»I он шинель ту расчапнув, голай жопай сєл на морду, жопай сєл на морду перястала біть» [2, с. 88].

Привертає увагу й те, що роль знахаря виконує чоловік, адже дослідниками зафіксовано чимало прикладів сідання матері або іншої жінки хворому на обличчя зі словами: «Чим тебе породила, тим і придавила» або «Чим тебе породила, тим i відходила», «Який гість, така й честь» тощо [Полесские заговоры 2003: 250; Колодюк 2006: 45]. Експедиційні записи підтверджують активне побутування цього звичаю по всьому ареалу Полісся. Як і в попередніх ситуаціях, такі дії мали символізувати друге народження або ж залякування персоніфікованої хвороби. Але семантика оголеності в такому випадку пояснювалася тим, що жінка сідає на голову місцем, з якого й народжується дитина. У наведеному наративі роль жінки та необхідності акту повторного народження вже не важлива для ритуалу. Замість неї активним агентом стає солдат, який у традиційній культурі постає як символічний чужий, прибулий з іншого світу, інколи трікстер, як у водевілі Івана Котляревського «Москаль-чарівник».

Окремо варто звернути увагу, що у цьому ритуалі оголення має не лише фертильну функцію, про що вже йшлося вище. Оголеність під час ворожінь, апотропеїчних та лікувально-магічних дій пояснюється потребою вдалого налаштування контакту з тим світом. Функції оголеності базуються на сприйнятті іiі як ознаки потойбіччя та природного стану, коли гола людина - вже або ще не зовсім людина [Агапкина, Валенцова, Топорков, 2004: 356].

Таким чином, необхідність виконання ритуалу оголеним може розглядатися 3 декількох сематично близьких позицій. Водночас сьогодні уявлення, що потрібно сісти на людину задом, пояснюється на сучасний лад потребою стабілізувати людину від час нападу: «Ну, пасядіш на йой, покуль яго атаб’ $\epsilon$ (...), шоб ня бівся» [1]. I, як ми бачимо, тут уже не йдеться про оголеність, а лише про прагматичність у допомозі хворому.

Отже, дослідження, яке відбувалося на території Семенівського та НовгородСіверського районів Чернігівської області, зафіксувало такі уявлення про причини 
появи епілепсії, як задавнений ляк або вроки, алкогольна залежність та вродженість. Серед опитаних шептух зберігається уявлення про можливість вилікувати епілепсію в дитячому чи ранньому підлітковому віці. Деякі респондентки для цього використовують універсальні молитви, орієнтовані на зурочення та ляк. Зафіксовані методи ірраціонального лікування здебільшого мають на меті обманути хворобу, вдаючись до символічного поховання й повторного народження, а також наближення до стану не-людини. До них належать накривання чорною хусткою, переступання через хворого на порозі церкви та сідання оголеним задом на хворого. Вірування про епілепсію та шляхи ії подолання піддаються відчутним впливам глобалізаційних процесів. Люди частіше звертаються до спеціалістів $з$ доказової медицини, проте ще зберігають тенденцію послуговуватися народними методами, коли мова йде про найперші прояви захворювання або зупинку нападу.

\section{ЛІТЕРАТУРА}

Агапкина, Т., Валенцова, М., Топорков, А. Нагота // Славянские древности. Этнолингвистический словарь. Москва 2004, т. 3, с. 355-359.

Ганус, Д. Магічні способи лікування епілепсії у дітей (за матеріалами польових досліджень населення західноукраӥнського пограниччя), «Наукові записки Вінницького державного педагогічного університету імені Михайла Коцюбинського. Серія: Історія», 2015, Вип. 23, С. 200-204.

Ганус, Д. Народна етіологія дитячих захворювань на території украйнсько-польського пограниччя // «Народна творчість та етнологія», 2016, № 6, С. 77-83.

Жаткович, Ю. Замітки етнографічні з Угорської Руси, «Етнографічний збірник», 1896, т. 2, с. 1-38.

Ігнатенко (Колодюк), I, Забловський, А. Профілактика хвороб і лікування дітей // Народна культура українців: життєвий цикл людини: історико-етнологічне дослідження у 5 т., наук. ред. М. Гримич, Київ 2008, с. 31-49.

Колодюк, I. Народна медицина у традиційній культурі українців Центрального Полісся (остання чверть XX - початок XXI ст.), Київ 2006.

Кравченко В. Звичаї в селі Забрідді та по деяких інших, недалеких від цього села місцевостях Житомирського повіту на Волині. Етнографічні матеріали, зібрані Кравченком Василем, Житомир 1920.

Маєрчик, М. Ритуал і тіло: структурно-семантичний аналіз українських обрядів родинного циклу, Київ 2011.

Никончук, М., Никончук, О., Мойсієнко, В. Поліська лексика народної медицини та лікувальної магії, Житомир 2001.

Петров, В. Вірування в вихор і чорна хороба // Етнографічний вісник, за голов. редагув. А. Лободи та В. Петрова, Київ 1926, Кн. 3, с. 102-106. 
Плотникова, А. Порог // Славянские древности. Этнолингвистический словарь. Москва 2009, т.4, с. 173-178.

Полесские заговоры (в записях 1970-1990 гг.), сост., подготовка текстов и коммент. Т. А. Агапкиной, Е. Е. Левкиевской, А. Л. Топоркова, Москва 2003.

Усачева, В. Контакты человека с демонами болезней: способы защиты и избавления от них // Миф в культуре: человек - не-человек, Москва 2000, с. 58-67.

Усачева, В. Падучая // Славянские древности. Этнолингвистический словарь. Москва 2004, т. 3, с. 611-616.

\section{Матеріали}

1. Матеріали, записані в с. Костобобрів Семенівського р-ну Чернігівської області // АА Державний науковий центр захисту культурної спадщини від техногенних катастроф (далі - ДНЦЗКСТК), Ф. Семенівка-2019, Од. зб. Д. Анцибор, АФ-Д.1

2. Матеріали, записані в с. Тимоновичі Семенівського р-ну Чернігівської області // АА ДНЦЗКСТК, Ф. Семенівка-2019, Од. зб. Д. Анцибор, АФ-Д.2

3. Матеріали, записані в с. Іванівка Семенівського р-ну Чернігівської області // AA ДНЦЗКСТК, Ф. Семенівка-2019, Од. зб. Д. Анцибор, АФ-Д.3

4. Матеріали, записані в с. Янжулівка Семенівського р-ну Чернігівської області // АА ДНЦЗКСТК, Ф. Семенівка-2019, Од. зб. Д. Анцибор, АФ-Д.4

5. Матеріали, записані в с. Орликівка Семенівського р-ну Чернігівської області // АА ДНЦЗКСТК, Ф. Семенівка-2019, Од. зб. Д. Анцибор, АФ-Д.5

6. Матеріали, записані в с. Жадова Семенівського р-ну Чернігівської області // AA ДНЦЗКСТК, Ф. Семенівка-2019, Од. зб. Д. Анцибор, АФ-Д.6

7. Матеріали, записані в с. Блистова Новгород-Сіверського р-ну Чернігівської області // АА ДНЦЗКСТК, Ф. Семенівка-2019, Од. зб. Д. Анцибор, АФ-Д.9 